\title{
\#FeesMustFall as social movement and emancipatory politics? Moving towards an apocalyptic theological praxis outside the limits of party politics
}

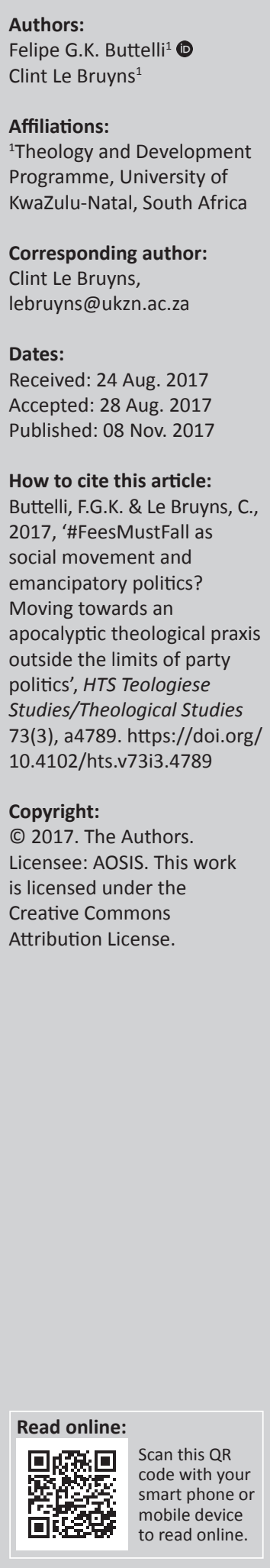

This article proposes three reflexive movements. The first one offers an introduction to Fees Must Fall, pointing to some aspects that allow us to understand it as a social movement and some of its basic features. The second movement is a theoretical one, constructing the notion of emancipatory politics. It is based on the distinctions suggested by Jacques Rancière between 'police and politics' and by Michael Neocosmos between 'excessive and expressive' politics. It will also present the Freirean notion of 'conscientisation and dialogicity', emphasising the learning experience from the political praxis within emancipatory social movements. The third movement offers, as conclusion, an apocalyptic politics as suggested by Žižek, envisioned through the lens of Christian eschatology, as a critical approach to social movements towards the radical transformation of society.

\section{Introduction - Approaching \#FeesMustFall}

The contemporary debates about social movements in South Africa are busy trying to understand the current students' movement called Fees Must Fall (also known by the twitter trending topic \#FeesMustFall or /\#FMF). Contradictory and ambiguous as all social movements can be, FMF raises polemical views and critical approaches. The movement started in 2015 as a continuity of Rhodes Must Fall (\#RhodesMustFall - RMF) (Naidoo 2016). As FMF struggled initially against the increase in fees in the academic year of 2016, RMF had before that a strong critical approach to the colonial heritage of South African universities. It started at the University of Cape Town (UCT) on March 2015 when a student, Chumani Maxwele, threw faeces on the statue of Cecil John Rhodes, an English coloniser and businessman who is notably known for his defence of scientific racism. This event raised what would become a countrywide students' movement calling for decolonisation of higher education in South Africa (Booysen 2016; Naicker 2016; Pillay 2016).

Although we have to be cautious because of the different narratives regarding the start of the movement, some scholars identify the beginning of the FMF movement at Wits University (Booysen 2016; Luescher, Loader \& Mugume 2016). The students declared that the increase in the university's tuition was unaffordable and that the $5 \%$ government subsidy would be insufficient to cover the impact in the cost of studying - including book fees, university tuition, research equipment and accommodation. In a broader sense, we can say that the movement has in its core, the plea for greater or universal access to higher education through free (decommodified) education.

Susan Booysen (2016) shows how the FMF students' turmoil has been labelled as both an uprising and a revolt. However, the students call themselves a movement. Ilse Scherer-Warren (2014), a Brazilian scholar of social movements, identifies that the:

organized social movements have a relative temporal permanence and in the contemporary world tend to be structured in the form of networks of militancy that operate as a strategy for a construction of common political or cultural meanings, aiming to conquer and mobilize citizens and to produce social transformations. (p. 14, [author's our translation])

FMF has many features that allow us to understand it as a social movement. One interesting aspect emphasised by Everatt (2016) is the relation between the contemporary protesters and the 'former liberators', understanding FMF as a social movement of political contestation. He asks to what extent students drink from that liberation tradition or rebel against those figures who are in power now. Another noteworthy aspect is the issue of power and class which can be identified in

Note: The collection entitled 'Spirit rising: tracing movements of justice', forms part of the 'Faith in the City' research project, hosted by the Centre for Contextual Ministry in the Faculty of Theology, University of Pretoria. Some of the articles were papers presented at the Biennial Consultation on Urban Ministry, hosted by the Institute for Urban Ministry, in collaboration with other organizations, from 17-20 August 2016. The theme of this Consultation was '\#We must rise: healers - dreamers-jesters'. 
FMF. Patrick Bond (2016) points to the critique of neoliberalism and the unequal distribution of investment of the tertiary education that is unveiled by the movement and that becomes a central aspect of it. The claim for free education challenges the neoliberal logic that is at the heart of the management of the universities in South Africa (but not exclusively). He recalls what is claimed by the movement, that 'to win free education, fossilised neoliberalism must fall' (Bond 2016:192). Besides that, Vishwas Satgar (2016) emphasises the existing relationship between the students' struggle and the workers' class struggle, especially in what relates with the protests against the outsourcing in the universities, which was also at the basis of the movement.

While we do not have extensive written documentation (some are still being published, especially from the Fallists themselves) regarding FMF, it is possible to see some analyses that understand the rise of this social movement related to a specific culture in South Africa. Some works analyse this historic context in order to understand the place and the role of social movements as FMF in South Africa. The first one, by Malcolm Ray (2016), relates the crisis in the universities with South African colonial history, considering the colonial type of education that coined the South African academic (schooling) system. Ray analyses the Black Consciousness Movement and how it was deeply related with the students' organisation and with the students' political activity. Like Bond, Ray connects the contemporary crisis with neoliberal capitalism and the 'neo-apartheid' that continues after the end of apartheid. The FMF movement is characterised as a movement within the whole critical and political analyses of the contemporary South Africa that is unable to deliver quality and universal services, such as free, decommodified, Afrocentric and quality education. This long analysis is also made extensively by the historian Sampie Terreblanche (2012) who identified the neoliberal turn after the end of apartheid as responsible for the country to be 'lost in transformation'.

Sharlene Swartz (2016), in her turn, draws on the actual situation of the country regarding social restitution in order to build Another Country. For her, the whole programme of decolonisation, which was also stressed by FMF:

must mean the making whole, the re-creation, re-appropriation and reconfiguration of space. It means more than simply eradicating the lines of force that keep zones apart; it requires fundamental social and economic change. (p. XV)

What FMF reminds and brings to the public debate is that, in most instances, this inequality remains divided along racial lines, where to be black means to be poor. For many black South Africans, it feels as if little transformation has taken place in the more than two decades since the fall of apartheid. These economic factors informed the climate in which both the RMF and FMF protests took place.

Leigh-Ann Naidoo (2016) is one of the activist students who give voice for the FMF movement. She sees it as the rise of the black-led movement, connecting FMF with the struggle for decolonisation of education of RMF. One aspect that she considers interesting to note is the intersectionality of the movement. As Naidoo (2016) says:

the movement acknowledged a number of oppressive systems in addition to racism and capitalism and was committed to trying to work against all oppressions that presented themselves in universities, and were also present within the student movements. (p. 182)

More broadly, Jane Duncan (2016) in Protest Nation analyses the right to protest in South Africa. It does not include only the students' protests, but mostly the activity of social movements in South Africa and the way these are repressed by the state and police forces. She advocates for the democratic right to protest as a way to civil society and social movements to qualify the democratic participation and accountability of the society. Besides South African examples, Duncan stresses two interesting aspects. The first one is the international character of the political repression against social movements and protesting movements. Especially those who are entering the public space, occupying and resisting, demanding for rights and democracy. The second aspect is the conditioned and distorted coverage of the media, mostly representing the interests of economic power and condemning the protesting movements.

It is important to understand the contemporary social movements from a political point of view. For that, we will present briefly five notions that will guide our understanding about the role of the new social movements in the contemporary global reality. The first notion comes from Slavoj Žižek. According to him, we can categorise FMF as a contemporary social movement that, within the local reality and with its particularities, is also part of the global struggles against capitalism and the new forms of repression pushed by it. Žižek (2015) says:

Global capitalism is a complex process that affects different countries in different ways, and what unifies the protests in their multiplicity is the fact that they are all reactions to different facets of capitalist globalization. Nowadays, a general trend of global capitalism is towards a great expansion of market dominance in combination with the progressive closure of public space, reduction of public services (health, education, culture) and the increase of authoritarianism. (pp. 127-128)

Žižek sees two main factors behind the action of these contesting movements. The first one is related - in nuanced levels of radicalism - with the economic aspects. Especially with the critique of corruption and inefficiency of the state in delivering services. The second factor is related with the political-ideological critique, demanding real and participatory democracy and exposing the fake democracy, mostly engulfed by the neoliberal logic and political power.

The second contribution is related with the notion of democracy. It is presented by Jacques Rancière (2006b) who establishes that contemporary democracy is, in fact, controlled and limited by an 'oligarchical State'. According to him, real democracy becomes a challenge to the governmental 
representative democracy. Signs of the real democracy are regarded by him as signs of an anarchical society. Concerning the social movements in such reality, he says:

Such was the demonstration developed throughout The Crisis of Democracy: what provokes the crisis is nothing other than the intensity of democratic life. But this intensity and its subsequent danger have two facets: on the one hand, 'democratic life' would seem to be identical to the 'anarchic' principle that affirms the power of the people [...]: persistent militant contestation in all domains of State activity; undermining of the principles of good government, of the respect for public authorities, of the knowledge of experts, and of the know-how of pragmatists. [...] Such is the standard form by which experts state the democratic paradox: as a social and political form of life, democracy is the reign of excess. This excess signifies the ruin of democratic government and must therefore be repressed by it. (pp. 7-8)

The third notion goes further in understanding the state of contemporary democracies. It is presented by Giorgio Agamben (2005) and stresses the fact that the global context - marked by the neoliberal attack on democracies to privatise the public resources - is thriving in creating 'permanent states of exception'. He formulates it as follows:

In this sense, modern totalitarianism can be defined as the establishment, by means of the state of exception, of a legal civil war that allows for the physical elimination not only of political adversaries but of entire categories of citizens who for some reason cannot be integrated into the political system [Palestinians, black youth, LGBTS, Indigenous Peoples ...]. Since then, the voluntary creation of a permanent state of emergency (though perhaps not declared in the technical sense) has become one of the essential practices of contemporary states, including socalled democratic ones. Faced with the unstoppable progression of what has been called a 'global civil war', the state of exception tends increasingly to appear as the dominant paradigm of government in contemporary politics. (p. 2, [addition in author's our translation])

The fourth notion comes from the sociologist Manuel Castells (2012:3), who analyses more closely the global social movements. Castells sees differences in the new social movements not only related to the technological revolution and globalisation, but also to the contemporary political, social and cultural context. He expresses it as follows:

The movements spread by contagion in a world networked by the wireless Internet and marked by fast, viral diffusion of images and ideas. They started in the South and in the North, in Tunisia and in Iceland, and from there the spark lit fire in a diverse social landscape devastated by greed and manipulation in all quarters of the blue planet. It was not just poverty, or the economic crisis, or the lack of democracy that caused the multifaceted rebellion. Of course, all these poignant manifestations of an unjust society and of an undemocratic polity were present in the protests. But it was primarily the humiliation provoked by the cynism and arrogance of those in power, be it financial, political or cultural, that brought together those who turned fear into outrage, and outrage into hope for a better humanity. A humanity that had to be reconstructed from scratch, escaping the multiple ideological and institutional traps that had led to dead ends again and again, forging a new path by treading it. It was the search for dignity amid the suffering of humiliation - recurrent themes in most of the movements. (p. 3)
The last reference that becomes crucial is the debate regarding the role of social movements and civil society in contemporary South Africa more specifically. Richard Pithouse helps us to understand how democracy is threatened by the contemporary state of affairs in politics and especially in economics in South Africa. Pithouse (2016a) notices how the persistent economic disparities and the political context maintain contemporary capitalism unchallenged. Pithouse, on his research and engagement with the Abahlali baseMjondolo, identifies the interconnectedness between the struggles on the ground, with, by and from the perspective of social movements, and the process of learning (2016b), as much as the resistance to capitalism. Although Pithouse has not studied the FMF movement, we can learn from him to understand how, in South African society, social movements have a history and an impact 'from below' that challenges and criticises the political establishment and the economic reality of the country.

Fees Must Fall, although a more 'loosely' organised and structured movement, still misses a solid articulation of its own political principles. Therefore, it has to be understood as a different movement as we compare it with Abahlali. It is also part of the new social movements (Abahlali started in the 1990s, after the end of apartheid): they are still open. Its definition and its political orientation are not clear yet. Furthermore, they are under disputation. That is why ambiguity, contradictions and limitations can be observed. But that might also be part of the characteristics of the contemporary social movements. Using Bauman's word, this 'fluidity' is at the core of the identity of these movements and it might be that they are never going to achieve a level of structuration and organisation as other forms of movements. If that is something that, for now, is difficult to identify - as the movement is still being defined and constructed - what we aim to do here is to give some landmarks to identify and to understand how these movements can be regarded as 'politics' in Rancière's terms, and how they articulate the possibility of emancipation, especially from a Freirean point of view.

\section{Social movements as politics and emancipatory movements}

This second movement of the article will introduce the underlying understanding that, in the current circumstance of capitalism - described as lacking democratic legitimacy true politics must be done outside the limits of the state. Rancière's understanding of 'the distribution of the sensitive' will guide us to establish some landmarks on how the dominant order of society is perpetuated and how social movements should act to do politics.

Rancière's (2006b) notion of democracy seems to be helpful and challenging in this sense. First of all, because he does consider the so-called 'liberal democracy' as an 'oligarchic state'. This oligarchic state allows certain forms of democratic representation, but its fundamental conception is already not democratic. His notion of democracy tends to lead to 
anarchism, as the real democracy would come from the impetus of contestation praxis towards the 'oligarchic state'. The real democracy, for him, only exists in the movements that contest the oligarchic state. For this reason, a social movement, as FMF, for instance, can only be contributing for democracy if it is challenging the political order. Real democracy, for Rancière, would be public demonstration that exposes 'liberal democracy' to its real face: a democratic order that is controlled by the ruling classes' economic and political interest. Representative democracy - as mostly defended as the most appropriate means to achieve democracy, according to liberal political thought - is limited and in the end reproduces the social division that is at the heart of the capitalist society. It means that when we listen to critiques of the social movements for not being willing to articulate its political interests as real proposals to be digested by the representative democracy (parties, political associations, civil society, etc.), that is rightly when they are acting genuinely democratically: they are tearing apart the veil of the oligarchic state and exposing the lack of democracy in the political system.

Another landmark suggested by Rancière is the distinction between police and politics (2010). Police is every practice that ensures the reproduction of the established order, in his words, a specific 'distribution of the sensitive' (2006a). The state, conceived as oligarchic, operates to maintain, justify, protect and reproduce that dominant order. It means that the struggle around the state will be characterised as a struggle within the dominant framework, therefore, not emancipatory, or, in his words, not 'politics'. The concept of politics, in turn, points to the emancipatory praxis that generates creative and contesting movements of change. It might only happen from outside the dominance of police, that is, the dominance of the established political order. Only real political activity (not party politics), in Rancière's view, can effectively change society. All political (emancipatory) movements tend to be, at certain point co-opted or engulfed by police, by the 'distribution of sensitive', by the dominant order, and eventually lose their liberative glimpse. In fact, it is very difficult for a political movement to reach that point in which it is not regulated by the police. And that is obviously related to the fact that the rancièrean 'police' has all the social institutions as the media, schooling system, churches and all the other means that are at the service of the reproduction of the dominant order operating to create and reproduce a specific 'distribution of the sensitive'.

Politics is rare and quick. It means that we have to be cautious in identifying a social movement as rancièrean 'politics'. It has to be sincerely and critically considered to what extent that social movement is really building new ideas and praxes and how it is dealing with the 'police', which permanently tries to co-opt those refreshing movements to the established order, to political parties, to the political system and so on. We take that critical remark seriously in account when we look at the dynamics of FMF and see the limits of the permanent process of political co-option that happens in many facets of the movement. According to Rancière, instead of empowering the movement, this party political interference is censoring the rancièrean political dimension of it, turning FMF into another instance of the police.

Michael Neocosmos (2016), a South African scholar, helps to contextualise Rancière's view to the South African context. He does it with special regards to social movements, identifying how the political dynamic in South Africa can be described as 'expressive thinking', which means - according to Rancière - police, under state's surveillance politics, which will always express and reproduce the dominant order. Social movement that moves into the political realm of the state loses its emancipatory potentiality and reproduces 'expressive thinking'. It means that the social movement, instead of renewing and refreshing the understanding of the society, becomes and settles for being a tool that expresses the dominant view of it. At the end, it cannot contribute to change the reality because it is an expression of the status quo. On the other hand, he does also discuss an 'excessive thinking', which exceeds the limits of the state and of police.

Therefore, we argue that for FMF and other social movements to become or to maintain its hope of transformation, it has to avoid becoming a reproduction of the party political debates and the defence of its representatives. According to Neocosmos and Rancière, this party division and the definition of the agenda for the movement by the parties and their representatives only condemn the movement to be locked inside the existing political framework. At the end, the discursive opposition is just apparent, as all the parties are part of the police and work for the reproduction of the political and economic order - an excluding and unjust 'distribution of the sensitive'.

After understanding what is politics, we will reflect about how the process of emancipation happens within the social movements. For that, Paulo Freire's notion of conscientisation (1987) becomes quite relevant. The process of conscientisation can be described as a process of learning that happens in concentric cycles of engagement between the political praxis of a subject and his or her immediate socio, political and economic reality. Starting from the perspective of dialectic historical materialism suggested by Karl Marx, his understanding considers this process fundamental in the struggle for transformation. The process of conscientisation enables a growing awareness of reality and a grounded theoretical knowledge that leads to a process of emancipation centred and guided by the subject of the knowledge. As Ana Lúcia Souza de Freitas (2016), a Brazilian theorist on Freire, describes it:

Conscientization, understood as process of critique of the conscience-world relations, is a condition for the assumption of the human commitment in the historic-social context. In the process of knowledge, man and woman tend to get committed with reality, being that a possibility that is related with the human praxis. It is through conscientization that the subjects take on their historic commitment in the process of making and remaking the world, within concrete possibilities, making and remaking themselves too. (p. 88, [author's our translation]) 
Paulo Freire was an educator, so, for him, the process of knowledge construction is not centred in the teacher, but has to initiate in the subject of the knowledge, the poor, the marginalised people, the people suffering under abusive conditions in society and the people who have their rights and their dignity violated. The role of the educator is understood as that of a mediator: the person who helps the student to see and understand his or her political and economic reality and from that place, from that personal engagement in the world, to act for its transformation. This dialectic, elliptic process that starts in the subject and moves into the world, transforming it, which will again affect the reality of the student - or could we say, the activist of a social movement - is a process of growing awareness. Subjects who are more aware of the reasons of their condition of oppression are better enabled to act in the world in an emancipatory way.

Social movements as collective and relational movements, which surpass individual political praxis, freirean's notion of dialogicity becomes important as a way to understand that no social movement builds up a conscientisation without a real ethics of dialogue. Dialogue means, for Freire, an attitude of love, respect, solidarity and democratic engagement with others. No authoritarian, hierarchical and despotic movement, even if including many people, yet centred in individuals who are not responsive to others, can lead to emancipation. Zitkoski (2016) describes Freire's notion of dialogue as follows:
dialogue is the force that pushes the critical-problematizing thinking in relation to the human condition in the world. Through dialogue we can say the world according our way of seeing it. Furthermore, dialogue implies a social praxis, that is the commitment between the spoken word and our humanizing action. This possibility opens ways to rethink life in society, to discuss about our cultural ethos, about our education, the language that we practise and the possibility of acting in another way of being, that transforms the world that surrounds us. (p. 117, [author's our translation])

Concluding this second movement, it is possible to understand that not all social movements are able to lead to an emancipatory praxis. According to Freire, the process of conscientisation requires a movement of subjects who can read and understand their reality and who are ready to act practically for the transformation of their economic and political conditions. This dialectical, spiral process can be mediated but never arbitrarily defined by any authority teachers, professors, politicians and so on. It requires the active participation, the personal and existential involvement of those who are affected by the reality of oppression. Secondly, the process of emancipation is never an individualistic one, it is never related to the promotion of personalities, but happens through an ethics of dialogue, in a collective construction that demands serious and respectful engagement with the 'otherness'. These landmarks can be useful to evaluate contemporary social movements, like FMF, in order to understand how it can be emancipatory politics or how, and why, do they fail when they are seriously affected by the ambiguous and contradictory practices that diminish their potentiality to be movements of change and transformation in contemporary societies.

\section{Conclusion - apocalyptic thought and the 'courage of hopelessness'}

The conclusion will drink from the polemic thinking of Žižek and Badiou. According to them, the best way to do emancipatory politics is to do - in party political sense nothing. We have to be brave to adhere to (party) political 'hopelessness', as the final stage of capitalism and of the oligarchic liberal democracy that will lead to its self- and automatic implosion. Doing nothing is the most radical thing to be done!

For Alain Badiou, 'it is essential to separate political practice from fascination with power' (2011:20). Badiou conceives politics as 'collective action, organized by certain principles, that aims to unfold the consequences of a new possibility which is currently repressed by the dominant order' (2008:31). He thus understands the 're-emergence' of the 'Communist Hypothesis' as fundamental in the current context of struggles against capitalism and its effects in the social and political realities:

The communist hypothesis is that a different collective organization is practicable, one that will eliminate the inequality of wealth and even the division of labour. The private appropriation of massive fortunes and their transmission by inheritance will disappear. The existence of a coercive state, separate from civil society, will no longer appear a necessity: a long process of reorganization based on a free association of producers will see it withering away. (2008:35)

Badiou as much as Žižek $(2015 ; 2017)$ state that in this 'apocalyptical interlude' in which the economic, political and social crises are accelerating, the best option within the political sphere is to do nothing. It requires us to be brave to wait until we get out of a timely order, to get out of this interlude of radicalisation of the capital crisis, as Badiou affirms; or to be brave to have no hope (at least the kind of hope offered within the framework of this established order) as Žižek states. Meanwhile, we can articulate the grassroots movements, reconstructing this 'communist hypothesis' to imagine and establish new praxes of emancipation that might lead us to another world (after the end of this one as we know it). And, exactly at this moment ... theology has a critical contribution to give to the political praxis. How to imagine and to announce prophetically another reality?

Allan Boesak (2005:223) understands that the eschatological dimension of theology 'liberates us from the stranglehold of historical predetermination and sensitizes us to dream of eschatological possibilities as protest against empirical reality'. For him, eschatology is rooted in our reasonable Christian hope (courageous hopelessness?). 'The fantasy we spoke of is not empty, without meaning or content, but a reasoned and 
reasonable account of the hope that is within us (1 Pet 3:15) (2005:223). Christian eschatology understands that the end of capitalism (or any other timely order) is the end of a present disaster, and we are always moving forward to new cycles of life, to new beginnings. So state Braaten and Jenson (1984):

Eschatology does not just mean discourse about the so-called 'last things', that which happens in the end. It must consider everything that is related to this end. Though the various movements toward the end do not constitute an unidirectional process, certain causes will undoubtedly urge more toward some ends than others $[\ldots]$ Often the eschaton, as that which stands at the end, is not regarded as the goal of a linear progression. It can be the cessation of all life cycles, as in the notion of reincarnation or of the return to the beginning, to the garden which humanity once inhabited and to which the blessed will regain access. (pp. 482-483)

Apocalyptic is an important dimension of eschatology. The apocalyptic genre gives the eschatological hope of God entering history and inaugurating God's kingdom as a symbolic language. Hope receives a body and a face. This heuristic exercise of apocalyptic imagination seems to be a powerful theological weapon when we think about the contemporary stage of capitalism and how it affects and co-opts the political activity of social movements. Art, culture and every form of human expression embedded in hope and resilient resistance is a source of transforming apocalyptic imagination. Regarding the way the churches can address this, Boesak (2009) affirms:

The church is called to resist all these new forms of idolatry, for they have enormous moral, political, economic and theological consequences. It seems to me that we shall have to begin by allowing for a new understanding of the imperial context of the New Testament, as well as the ways in which traditional Christian theology, as shaped by Western Europe and Euro-American thinking and interpretation, have left us ill-prepared for dealing with the theological, political and economic realities the church is facing today. We need, in other words, a process of 'decolonization', a process that will help us undo the domestication of Jesus, Paul and the writings of the New Testament that has proved so harmful in the history of Western Christianity. [...] we shall have to engage in hard political and economic analysis of our imperial realities today, the manifestations of globalization and its impact on the world and on the communities where we live, work and worship and on the life of the church. Over against the 'false promises' of empire we shall have to proclaim the promises of God in Jesus Christ, which are diametrically opposed to the promises of empire. [...] we shall have to deny claims that the reality of empire is so overwhelming as to be unchallengeable and unchangeable as if it were ordained by divine sanction. We shall have to resist all absolutist claims. (p. 72)

In this way, the theological reflection and the praxis of the churches can be articulated by and with social movements, building hopes, apocalyptic imagination from the dialogical experience by the emancipatory movements. In fact, if the churches in their manifold forms in society want to have any impact in helping to create a new social, political and economic order, it can only do so by working together, located among and within the social movements that are experiencing something new, something not known and something that we still cannot define with words and concepts. Only after this long conversation and this long exercise of collective imagination - without doing anything in the party political sphere - we might be able to cross out the limits of the present distribution of the sensitive, inaugurating a genuine political praxis of emancipation that exceeds the party political vicious patterns. But it demands nothing less than courage - the courage of hopelessness.

\section{Acknowledgements}

We are thankful for the readings and critical engagement by Prof. Dr. Anne Harley and Felipe Tonial.

\section{Competing interests}

The authors declare that they have no financial or personal relationships which may have inappropriately influenced them in writing this article.

\section{Authors' contributions}

Collaborative scholarly engagement between both authors as activist-theologians around grassroots struggles. F.G.K.B. wrote the draft version based in common activism and joint theoretical reflection with C.L.B., the supervisor. C.L.B. revised the text and gave substantial feedback to improve the draft. Both F.G.K.B. and C.L.B. approved the final version.

\section{References}

Agamben, G., 2005, State of exception, The University of Chicago Press, Chicago, IL. Badiou, A., 2008, 'The communist hypothesis', New Left Review 49, 29-42.

Badiou, A., 2011, 'Le socialism est-il le reel don't le communism est l'Idée?', in A. Badiou \& S. Žižek (eds.), L’Idée du Communisme', pp. 9-22, Lignes, Paris.

Boesak, A., 2005, The tenderness of conscience: African renaissance and the spirituality of politics, Stellenbosch, Sun Press.

Boesak, A., 2009, 'Theological reflections on empire', in A. Boesak \& L. Hansen (eds.), Globalization: The politics of empire, justice and the life of faith, Sun Press, Stellenbosch.

Bond, P., 2016, 'To win free education, fossilized neoliberalism must fall', in S. Booysen (ed.), Fees must fall: Student revolt, decolonisation and governance in South Africa, pp. 192-213, Wits University Press, Johannesburg.

Booysen, S. (ed.), 2016, Fees must fall: Student revolt, decolonisation and governance in South Africa, Wits University Press, Johannesburg.

Braaten, C. \& Jenson, R. (eds.), 1984, Christian dogmatics, vol. 2, Fortress Press, Philadelphia, PA.

Castells, M., 2012, Networks of outrage and hope, Social Movements in Internet Age, Polity, Cambridge.

Duncan, J., 2016, Protest nation: The right to protest in South Africa, UKZN Press, Pietermaritzburg.

Everatt, D., 2016, 'Standing on the shoulders of Giants? Successive generations of youth sacrifice in South Africa', in S. Booysen (ed.), Fees must fall: Student revolt, decolonisation and governance in South Africa, pp. 126-147, Wits University decolonisation and
Press, Johannesburg.

Freitas, A.L.S., 2016, 'Conscientização', in E. Streck, E. Redin \& J. Zitkoski (eds.), Dicionário Paulo Freire, pp. 88-89, Autêntica Editora, Belo Horizonte.

Freire, P., 1987, Pedagogia do Oprimido. 17ㅇe edn., Paz e Terra, Rio de Janeiro.

Luescher, T., Loader, L. \& Mugume, T., 2016, '\#FeesMustFall: An Internet-age student movement in South Africa and the case of the University of the Free State', Politikon 1-15.

Naicker, C., 2016, 'From Marikana to \#feesmustfall: The Praxis of Popular Protest in South Africa', Urbanisation 1(1), 53-61. https://doi.org/10.1177/2455747116640434

Naidoo, L.A., 2016, 'Contemporary student politics in South Africa: The rise of the black-led student movements of \#RodhesMustFall and \#FeesMustFall in 2015', in A. Heffernan \& N. Nieftagodien (eds.), Students must rise, youth struggle in South Africa before and beyond Soweto '76, Wits University Press, Johannesburg.

Neocosmos, M., 2016, 'Constructing the domain of freedom: Thinking politics at a distance from the state', Journal of Contemporary African Studies 1-16. https:// doi.org/10.1080/02589001.2016.1236876

Pillay, S., 2016, 'Silence is violence: (Critical) psychology in an era of Rhodes must fall and fees must fall', South African Journal of Psychology 46(2), 155-159. https:// doi.org/10.1177/0081246316636766

Pithouse, R., 2016a, Writing the decline on the struggle for South Africa's democracy, Jakana Media, Johannesburg. 
Pithouse, R., 2016b, 'Our struggle is thought, on the ground, running', in The University of Abahlali Basemjondolo (ed.), Centre for Civil Society Research report, No 40, Durban, University of KwaZulu-Natal.

Rancière, J., 2006a, The politics of aesthetics: The distribution of the sensible, Continuum, London.

Rancière, J., 2006b, Hatred of democracy, Verso, London.

Rancière, J., 2010, Dissensus: On politics and aesthetics, Continuum, London.

Ray, M., 2016, Free fall: Why South African universities are in a race against time, Bookstorm, Johannesburg.

Satgar, V., 2016, 'Bringing class back in: Against outsourcing during \#FeesMustFall at Wits', in S. Booysen (ed.), Fees must fall: Student revolt, decolonisation and governance in South Africa, pp. 214-234, Wits University Press, Johannesburg.
Scherer-Warren, I., 2014, 'Dos movimentos sociais às manifestações de rua: o ativismo brasileiro no século XXI', Política e Sociedade. Revista de Sociologia Política 13(28), 13-34.

Swartz, S., 2016, Another country: Everyday social restitution, Human Sciences Research Council, Pretoria.

Terreblanche, S., 2012, Lost in transformation: South Africa's search for a new future since 1986, KMM Review Publishing Company, Johannesburg.

Zitkoski, J.J., 2016, 'Diálogo/Dialogicidade', in E. Streck, E. Redin \& J. Zitkoski (eds.), Dicionário Paulo Freire, pp. 117-118, Autêntica Editora, Belo Horizonte.

Žižek, S., 2015, Trouble in paradise: From the end of history to the end of capitalism, Penguin Books, London.

Žižek, S., 2017, The courage of hopelessness: Chronicles of a year of acting dangerously, Allan Lane, London. 